
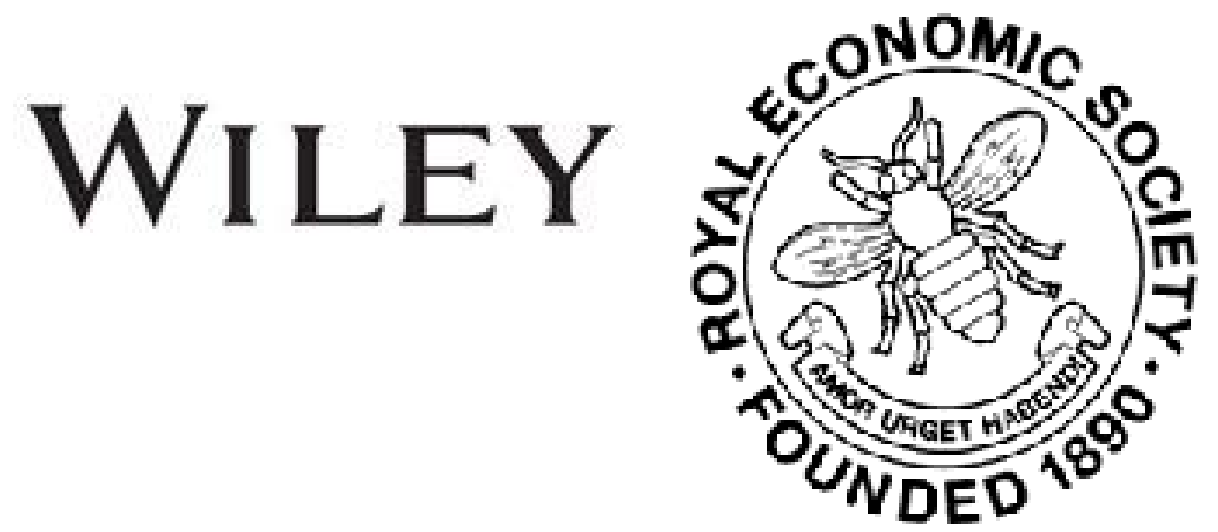

\title{
Review
}

Author(s): James Bonar

Review by: James Bonar

Source: The Economic Journal, Vol. 2, No. 7 (Sep., 1892), pp. 525-526

Published by: Wiley on behalf of the Royal Economic Society

Stable URL: http://www.jstor.org/stable/2955981

Accessed: 26-06-2016 13:01 UTC

Your use of the JSTOR archive indicates your acceptance of the Terms \& Conditions of Use, available at

http://about.jstor.org/terms

JSTOR is a not-for-profit service that helps scholars, researchers, and students discover, use, and build upon a wide range of content in a trusted digital archive. We use information technology and tools to increase productivity and facilitate new forms of scholarship. For more information about JSTOR, please contact support@jstor.org.

Wiley, Royal Economic Society are collaborating with JSTOR to digitize, preserve and extend access to The Economic Journal 
of the different writers. Not even Homer brings forward all his Greeks at once, but makes one the hero of the third, another of the fifth book; so upon the present occasion, without disparagement to the rest of the staff we shall confine ourselves to noticing the excellence of a particular set of articles-Mr. Bonar's biographies of Bentham, Chalmers, Cobden, and other publicists. He brings the main results of each life most artistically into focus ; and assists those who wish to scrutinize the details by a complete apparatus of references.

Taking a general view of the dictionary, one may attribute to it two qualities which are particularly appropriate to a dictionary, and to one whose subject is political economy, namely, terseness and a judicial character. It must have required great firmness in the editor to restrain within due proportions each specialist overflowing with the importance of his particular subject. To the advantage of brevity has been added that of variety by the original and commendable practice of allowing a debateable subject to be considered by two (or more) writers from different points of view. In short $\mathrm{Mr}$. Palgrave may be congratulated on fulfilling the aim which he proposed 'to place in the hands of the reader brief, carefully arranged, and well-digested statements which may assist him in the interpretation of authorities and in the formation of independent opinions.' It might be argued that the advantages proposed would have been more fully realised if the direction of the work had been in the hands of a committee rather than an individual. However that may be, the organisation of Palgrave's Dictionary will remain a monument of what may be accomplished by individual initiative and energy.

F. Y. Edgeworth

\section{The Call for Currency Refor'm, and Mr. Goschen's Response.}

By G. H. Dick and Jas. Mavor. (Effingham Wilson, 1892.)

THIs is a very useful pamphlet, from its clear summary of recent events and statement of the situation generally, as well as from its sensible comments on the proposal of the late Chancellor of the Exchequer. The 'call for currency reform' is (shortly) the appeal of the man of business and the professor for such joint international action in regard to the coinage of silver as will prevent the excessive fluctuations in its value that now demoralize trade, especially trade with the East. The steadying of silver is connected, not remotely, with the second reform discussed in this pamphlet, the securing of a strong metallic reserve in the Bank of England. Mr. Goschen's proposals (in their modified form, as presented in the letter to the Governor of the Bank of England, December 1891) are described as essentially in need of supplement, the supplement of his earlier suggestions (not pressed but not retracted by him) about a silver reserve and international action in regard to silver currency. Otherwise Messrs. Mavor and Dick consider that his scheme would - intensify the pressure on gold and increase the difficulties of monetary 
reform' (p. 28). 'The money would be drawn to the centre only to be scattered to the circumference' (p. 27). This is not obvious. The five millions of one pound notes issued on securities, as distinguished from the twenty millions issued against gold (to take the example given), would be a gain to the banking reserve of the Bank of England. This is implied in Mr. Gosehen's letter to Mr. Samuel Montagu (January, 1892) ; and in any case we could hardly suppose, when the whole intention of the scheme is to increase the reserve of the banking department, that the Bank would be allowed to disperse the gold got for the said five millions in any way it chose.

JAMES BONAR

\section{Il Diritto Pubblico nei Sistemi Finanziarii. By C. A. Coniglanan. (Bologna, 1892.)}

IN studying financial institutions it is essential to bear in mind that they have other aspects than the economic one. Roscher's proposition that each economic system hás a corresponding legal system as its background holds good of the public economy, and even for the economist the examination of the several jural phases of the State's financial action is of interest. In brief outline Dr. Conigliani traces the several steps by which existing ideas on the law of the budget have been evolved. From the 'patrimonial' state, where no idea of general utility exists and the sole law is the ruler's will (p. 7), the modern constitutional system has been gradually reached. Classical antiquity, feudalism, the Italian Communes, and England since the Restoration are types of the stages by which the existing situation has been attained; and this juridical development is traceable both in respect to expenditure and revenue.

Though admitting the great and obvious advantages of the present jural conception in respect to finance, the author adds a word of warning. Instead of the old privileges of individuals or political classes, may we not have a tyranny of the classes that are economically strongest? That such a result may happen can hardly be denied, but it seems that the greatest danger in modern finance is not the intelligent pursuit of its interest by the strongest class : it is rather the disposition to be led astray by 'the illusions of self-interest ill-understood' that is equally disastrous to every section of the society affected. The true remedy for errors of this kind is only to be found in the costly teaching of experience, which is best supplied under the modern legal and constitutional system.

C. F. BAstable

\section{Beitrïge zur Wahrungsfrage in Esterreich-Ungarn. VoN C. Menger. (Jena, 1892.)}

IN this essay the distinguished leader of the Austrian school deals with the practical question of the projected reform of the Austrian monetary standard. After a preliminary survey of the events which 